\title{
THE UNIFORM LAW ON THE INTERNATIONAL SALE OF GOODS: A REPLY TO PROFESSOR NADELMANN
}

\author{
ANDRÉ TUNC†
}

Professor Nadelmann's article on the Uniform Law on the International Sale of Goods ${ }^{1}$ is stimulating and, on the whole, probably useful. Certain historical inaccuracies, however, diminish the article's utility. This short reply is an attempt to clarify the record.

Nadelmann's first sentence ${ }^{2}$ leaves the reader with the impression that the participants at the Hague in April, 1964, hastily enacted a uniform law behind the backs of American importers and exporters. One can hardly say that the Uniform Law was "rushed through at a diplomatic conference." For, as Professor Nadelmann admits, the movement towards codification of the substantive aspects of the law of international sales began in the late 1920's. It is true that the Hague Conference was brief - twenty-four days. But the delegates to the Hague did not write on a clean slate. A draft of the Uniform Law was submitted in 1956 to some twenty governments which had participated in a conference in 1951 on the pre-war draft. A 1962 revision of the 1956 draft was the subject matter before the Hague Conference in 1964.

Perhaps when Professor Nadelmann characterizes the activities at the Hague as rushed he is subtly reflecting on the difficulties of international conferences. As a practical matter, in the modern world, it is extremely wishiul possibly Utopian - to expect conferees of the requisite caliber to remain in a foreign city for more than a month and to take the time necessary to investigate and discuss every detail - a task which is not theirs, in any event. Moreover, even if the conference could have been prolonged without attrition in the ranks,

TProfessor of Law, University of Paris; Head of the French Delegation, Diplomatic Conference on the Unification of Law Governing the International Sale of Goods.

1. Kurt H. Nadelmann, The Uniform Law On The Internatiosal Sale of Goods: $A$ Conflict of Lazus Imbroglio, 74 YaLE L.J. 449 (1965).

2. "With little advance notice, American importers and exporters today face the discomforting possibility of being subject to a uniform law of world-wide application to the international sale of goods, rushed through at a diplomatic conference held at the Hague in April, 1964." Ibid. (emphasis added).

3. Ibid.

4. After his general comments on the conference at the Hague, Professor Nadelmann next discusses a movement, begun in 1924, which culminated in the adoption of a convention governing conflict of laws. Id. at 450-52. Coming back to the issue of uniform sales law, id. at 453, Professor Nadelmann briefly notes the long history preceding the Hague Conference.

5. Professor Nadelmann notes that the United States had an observer present at the 1951 Conference, id. at 453, and that the United States secmed to have "expressed no interest in the venture." Id. at 456. 
past experience with international conferences offers no indication that the quality of the work produced varies directly with time consumed.

Another of Nadelmann's sentences may also be misleading: "That the United States had not participated in the preparation of the drafts made no differonce to this group; the United States, it was argued, had expressed no interest in the venture. ..." If this statement means that the delegates did not regret the absence of United States participation, it is wrong. Considering the unique importance of the United States in international trade, no conference concerning international sales could but regret American absence. Certainly, this is not to reproach Professor Nadelmann or other American scholars who have, over the years, urged the United States government to participate in the effort to codify the law of international sales. Equally, the delegates of other countries which have encouraged American participation in the movement ought not to be criticized. But delegates who did not encourage American participation ought not to bear the responsibility for the latter's lack of interest in the project.

A further word is in order regarding the response which the conference should have made to the United States' presence at the Hague. Nadelmann states that " $[a] n$ adjournment of final action for a year or so would have given the needed time for further improvement and accommodations between legal systems. ..." This reflects unbridled optimism; as one who was involved in the work both of the Special Commission and of the Drafting Committec, I think the position untenable. Modification of the Uniform Law to render it more susceptible of American ratification (and one must hope for such modification) would realistically require at least five years. What, then, should have been done when, a few months before the conference, and after the Netherlands had invited all governments, the United States expressed its interest in the Uniform Law? Should the conference have been cancelled - only to resume the long process of appointing a new Special Commission, discussing and, possibly, agreeing on a draft, printing and distributing it to the participating governments for submission to commercial circles? Was there a country willing to support the work of a new Special Commission, as had the Netherlands prior to 1964 ? Finally, what interest would the world community show in future drafts? Perhaps it is not too much to suggest that the Uniform Law had been long enough in the making and that subsequent delays could only have instituted a process of continuing revision and re-revision - a process which would have delayed enactment until the zeal for perfection died of exhaustion.

With respect to adjournment, the United States delegation to the Hague adopted the only position it could. Realizing the practical and psychological impossibility of adjourning the conference, it did not ask for a postponement.

6. Id. at 455-56 (emphasis added).

7. Id. at 456 . The sentence continues ". . . but whether or not all delegations cared for such accommodations is an open question." 
Nor, to my knowledge, did it sound out other delegations regarding support of such a motion. The United States delegation in a positive and helpful manner offered amendments which would have brought the Uniform Law closer to the Uniform Commercial Code. ${ }^{8}$ The conference accepted some amendments, though it rejected many. Of the latter, some probably would have improved the draft. But the draft presented had been considered in the commercial circles of various nations, and the introduction at the conference of different concepts and solutions would have endangered ratification.

The head of the United States delegation expressed the hope that eventually the Uniform Law and the Uniform Commercial Code might be more nearly consonant. This is surely a reasonable goal, one to which I fully subscribe. I believe, however, that ratification of the Uniform Law at the Hague is a necessary and important step towards a truly world-wide unification of the law of sales. ${ }^{9}$ Once a document has received sufficient consideration, as has the Uniform Law, only a test of life will reveal its strengths and weaknesses.

Another matter deserving of comment raises a sensitive issue: the Uniform Law's direction to the forum to apply the Uniform Law to international transactions even if the parties have their places of business in the territories of states which have not ratified the convention. Professor Nadelmann, pardonably, pokes fun at the Special Commission's feeling that the Uniform Law "contains rules which ... appear superior to the national laws." ${ }^{10}$ Yet, carlier in his article, Nadelmann observes that "for international sales a uniform substantive law is perhaps the ideal solution." quire application of the Uniform Law in the face of conflicting local law. Furthermore, the Special Commission did not state that the Uniform Law was per se superior to national laws, but rather that it was superior for the purpose of international trade. ${ }^{12}$

Any national law (even the law of sales) contains rules which grew out of a long tradition but which have little rational basis. The application of such rules to a party unacquainted with them may result in surprise and hardship. One hopes that the Uniform Law is free of such peculiarities. It has been worked on and agreed upon by common lawyers and civilians from many countries and many political systems. When parties to a contract have made

8. The United States delegation also offered the services of an expert, Professor John Honnold, to the Drafting Committee. That committee also included representatives from Great Britain, Holland, Germany and France.

9. The Uniform Law is not in the least intended to be a European document; it may be ratified by countries in Africa, Latin America and Asia.

10. Nadelmann, supra note 1 at 458 .

11. Id. at 450 .

12. A mistake seems to have occurred in the English translation of the paragraph quoted by Professor Nadelmann, id. at 458. The original text rezds as follows:

Elle continue à la penser souhaitable, la loi uniforme contenant pour le commerce international des règles qui lui semblent supéricures aux lois nationales.

The words "for international commerce" have been misplaced in the translation. 
no choice of law, "express or implied,"13 is it not safer for them to have their contract governed by the Uniform Law rather than by the law designated by conflict of laws rules?

No one pretends that the solution to the conflict of laws problem reached at the Hague is perfect. One may say, however, that the decision was reached only after full consideration of the issue. A judge of the Court of Appeal of Paris, M. Pierre Bellet, consulted on the matter with the various delegations for two weeks during the conference. His report to the conference was warmly received; the heads of some delegations which knew that the French delegation would vote for the text of Article $I$ as it is finally drafted ${ }^{14}$ and which planned to vote against the French position expressed their satisfaction with the completeness, objectivity and clarity of the report. In any case, the solution agreed upon by the majority of the conference will not be forced upon any contracting State. According to Article III of the Convention:

By way of derogation from Article I of the Uniform Law, any State may, at the time of the deposit of its instrument of ratification of or accession to the present Convention declare by a notification addressed to the Government of the Netherlands that it will apply the Uniform Law only if each of the parties to the contract of sale has his place of business or, if he has no place of business, his habitual residence in the territory of a differ. ent Contracting State, and in consequence may insert the word "Contract-

13. See Article III: "The parties to a contract of sale shall be free to cxclede the application thereto of the present Law either entirely or partially. Such exclusion may be express or implied."

14. Article I:

1. The present Law shall apply to contracts of sale of goods entered into by parties whose places of business are in the territories of different States, in cach of the following cases:

(a) where the contract involves the sale of goods which are at the time of the conclusion of the contract in the course of carriage or will be carried from the territory of one State to the territory of another;

(b) where the acts constituting the offer and the acceptance have been effected in the territories of different States;

(c) where delivery of the goods is to be made in the territory of a State other than that within whose territory the acts constituting the offer and the acceptance have been effected.

2. Where a party to the contract does not have a place of business, reference shall be made to his habitual residence.

3. The application of the present Law shall not depend on the nationality of the parties.

4. In the case of contracts by correspondence, offer and acceptance shall be cons sidered to have been effected in the territory of the same State only if the letters, telegrams or other documentary communications which contain them have been sent and received in the territory of that State.

5. For the purpose of determining whether the parties have their places of business or habitual residences in "different States," any two or more States shall not be considered to be "different States" if a valid declaration to that effect made under Article II of the Convention dated the 1st day of July 1964 relating to a Uniform Law on the International Sale of Goods is in force in respect of them. 
ing" before the word "States" where the latter word first occurs in paragraph 1 of Article I of the Uniform Law.

The reservation provided for in Article III is of greatest importance to those states which are troubled by the breadth of Article I, particularly because of the broad jurisdiction asserted by their courts. ${ }^{15}$ For those states which have ratified the Convention on the Law Applicable to International Sales of Goods, Article IV of the Uniform Law provides the solution:

Any State which has previously ratified or acceded to one or more Conventions on conflict of laws in respect of the international sale of goods may, at the time of the deposit of its instrument of ratification of or accession to the present Convention, declare by a notification addressed to the Government of the Netherlands that it will apply the Uniform Law in cases governed by one of those previous Conventions only if that Convention itself requires the application of the Uniform Law.

Four small matters remain.

(1) Professor Nadelmann states that "[I]n looking at these events the present political climate in Western Europe must be taken into account."1B I strongly protest against this allegation. ${ }^{17}$ Polities played no part at the Hague. The climate of cooperation between all delegations was exceptionally pleasant.

(2) Professor Nadelmann suggests that the Uniform Law is not favored in British commercial circles. ${ }^{18}$ Reportedly, these circles have changed their mind with a deeper consideration of the draft. In any event, Great Britain, which was represented at the Hague Conference by a delegation of high caliber, is among the six states which have signed the Uniform Law ; ratification by Great Britain seems likely, with the important reservation mentioned by Professor Nadelmann.19

(3) Professor Nadelmann suggests also that the present writer conceives of the Uniform Law as a continental venture, a conception at odds with that of Dr. Ernst Rabel. ${ }^{20} \mathrm{I}$ am, and always have been, aware of early and continuing English partnership in the project. And it is patently wrong to suggest that I do not share Dr. Rabel's hope for a truly international agreement on a Uniform Law. Neither Dr. Rabel nor I could have forced unwilling governments to participate in the work of the Special Commission. It would be unfair to infer from our lack of power satisfaction with or a lack of interest in recalcitrant governments.

(4) Finally, at one point in his article, Professor Nadelmann implies that I was unwilling to consider American views at the Hague because revisions

15. Normally, however, European courts do not assert jurisdiction over transactions which have only minimal connections with the forum state.

16. Nadelmann, supra note 1 at 456.

17. Anyone suspecting the present writer of anti-American feelings may as well waste 50 cents and buy his last booklet, LE dRorr DES ETATs-Unis ("Que sais-je", Presses Universitaires de France, 1965).

18. Nadelmann, stipra note 1 at 456 .

19. Ibid.

20. Id. at 460 . 
embracing such views would have dislodged "meritorious continental practices." 21 If this, in turn, is to imply that I followed any selfish continental interests, it seems puzzling. In fact, I have been criticized on the continent for my willingness to accept "concessions." Perhaps no one can work for a uniform codification without falling prey to criticism. International unification of the law is extremely difficult. The difficulties will, hopefully, be more fully appreciated when the work is more widely shared.

21. Ibid. Earlier Nadelmann states: "Some may have thought that a solid phalanx of continental nations could force American and English trade into submitting to the Uniform Law." Id. at 456.

The suggestion that there might have been pressure to force British acceptance of a continental draft is clearly wrong. Every effort was made to render the Uniform Law acceptable to Great Britain - so much so that some continental countrics may hesitate to ratify what appears to them (wrongly) a basically English document. Nadelmann's further suggestion that a "phalanx" might have tried to force American adoption of tho Uniform Law hardly conforms to the spirit of amity which existed between the hypothetical adversaries. See n. 8 supra. 


\section{THE YALE LAW JOURNAL}

\section{VOLUME 74 \\ JULY 1965 \\ Nuarber 8}

Peter L. Zistroth

Editor-in-Chief

E. EDWard Bruce

Cameron F. MacRae, III

Benno C. Scharmt, Jr.

Larry G. Staron

Note \& Comment

Editors

\author{
Bersy Levin \\ Topics Editor \\ Rayarond C. Cuevenger, III \\ MIARK A. WALKER \\ Article \& Book \\ Review Editors
}

Denris E. Curtis

Managing Editor

JOHN R. ADLER

CFarLes N. Burger

WaLter E. Dellinger, III

W. LeE H. Dunhaxs

Gregory C. GlynN

RICHARD GOODYEAR

H. JefF GREenfield

Cenarles H. Herz

B. Boyd Hight, Jr.
C. Stephen Howard Grorge L. JuRow LINDSEY C. Y. KIANG Howard A. KNTGET Staron Lazarus, III RONALD F. LIPP FREDERICE B. MICLANE JOSEPH N. ONEK
Charles a. Pulaski, Je. LEONARD MI. RosS Philit Gordorr Schirac Alan D. Sistrsky Altan G. SperLING Leonaro P. Strucriatan David F. Tulotson A.iceinaz S. Wazd ROBERT F. WALFER
Carolyn Jones

Business Manager
Bella Serdenanuss

Business Secrelory

\section{CONTRIBUTORS TO THIS ISSUE}

Harlan A. BLAKE. B.A. 1946, M.A. 1947, J.D. 1954, University of Chicago.

JACK A. Bruar. B.A. 1962, Bard College; LL.B. 1965, Columbia University.

Charles A. Reich. B.A. 1949, Oberlin; LL.B. 1952, Yale University.

ANDRE Tunc, docteur en droit Paris, 1941; docteur H. C. Université libre de Bruxelles 1958.

Leonard B. Boudin. B.S.S. 1933, College of the City of Nev York; LL.B. 1935, St. John's University.

Marshall CoHen. B.A. 1951, Dartmouth College; A1.A. 1953, Harvard University; Junior Fellow, Society of Fellows 1955-58, Harvard University. 